\title{
Development of Pure Culture Starter Using a White-Spored Mutant of Koji Mold, K-1A for Kecap, an Indonesian Soy Sauce
}

\author{
Joko SULISTYO ${ }^{1}$ and Sayuki NIKKUNI ${ }^{2 *}$ \\ ${ }^{1}$ Research Center for Biology, Indonesian Institute of Sciences \\ (Jl. Ir. H. Juanda No.18, Bogor 16002, Indonesia) \\ ${ }^{2}$ Food Science and Technology Division, Japan International Research Center for Agricultural \\ Sciences (JIRCAS) (Tsukuba, Ibaraki 305-8686, Japan)
}

\begin{abstract}
In order to prevent aflatoxin contamination in the production of kecap, an Indonesian soy sauce, the starter culture was prepared using the white-spored mutant K-1A strain induced from the aflatoxinnegative koji mold, Aspergills sp. K-1 and applied to koji making process of kecap. The number of spores developed on the cooked rice inoculated with $\mathrm{K}-1 \mathrm{~A}$ was not so different from that of $\mathrm{K}-1$. The germination ability of $\mathrm{K}-1 \mathrm{~A}$ after storing at $30^{\circ} \mathrm{C}$ and $75 \% \mathrm{RH}$ for 3 weeks was also not so different from that of K-1. While kecap koji making process took 9 days by conventional method (without inoculum), the use of the starter culture shortened the process to 3 days at room temperature. Since the inoculated strain K-1A developed white conidia (spores) during incubation, the mutant could be distinguished from contaminated aspergilli by their appearances on agar plates. The number (cfu/g) of contaminated aspergilli in the kecap koji from the environment decreased to $1 / 10$ by using the starter culture. The kecap mash prepared with the kecap koji inoculated with the starter contained higher formol nitrogen and water-soluble nitrogen than those prepared with the koji without any starter. These results demonstrate that the use of the white-spored mutant as a starter not only contributes to the prevention of aflatoxin contamination but also improves the conventional kecap fermentation process.
\end{abstract}

Discipline: Food

Additional key words: aflatoxin, Aspergillus

\section{Introduction}

Kecap is an Indonesian soy sauce and there are two type of kecap, sweetened soy sauce (kecap manis) and salty soy sauce (kecap asin). The sweetened variety is most popular? ${ }^{7}$ Kecap is made by spreading cooked soybeans on a bamboo tray and leaving for a period to make molded soybeans (kecap koji). The molded soybeans are then mixed with salt solution to carry out the second stage of fermentation under ca. $20 \%$ salt solution for 14 to 120 days at room temperature ${ }^{7}$. Then the fermented mash is filtered. To make kecap manis, the filtrate is mixed with palm sugar and spices, boiled for 4 to $5 \mathrm{~h}$ and filtered ${ }^{7}$. Kecap manis contains 26 to $65 \%$ carbohydrate, 0.1 to $0.3 \%$ total nitrogen and 3 to $9 \%$ salt $^{3}$.
Since kecap manufacturers do not usually use any inoculum in kecap koji preparation, molds grow on the surface of cooked soybeans as the result of infection from the environment such as the air and the previously used trays ${ }^{3,5,7}$. Molds isolated from kecap koji were mostly from the genus of Aspergillus ${ }^{3,5}$ and we isolated aflatoxin producers from Indonesian soybean koji samples ${ }^{5}$. According to Sadjono et al. ${ }^{6}$, approximately $47 \%$ of 32 samples of Indonesian kecap tested contained aflatoxin $\mathrm{B}_{1}$ at concentrations exceeding $5 \mu \mathrm{g} / \mathrm{kg}$. Therefore, the possibility of aflatoxin contamination cannot be ruled out in traditional koji making process and it is thus necessary to use a pure culture starter from the standpoint of food safety. In our previous paper, we induced the whitespored mutant, K-1A from the selected Aspergillus strain, K-1 (aflatoxin-negative koji mold) by irradiation of ultra-

\footnotetext{
Present address:

${ }^{2}$ National Institute of Livestock and Grassland Science (Tsukuba, Ibaraki 305-0901, Japan)

*Corresponding author: fax +81-29-838-8683; e-mail nikkuni@affrc.go.jp

Received 23 June 2005; accepted 26 August 2005.
} 
violet rays to distinguish the mutant from aflatoxin-producing molds. We applied it to kecap fermentation using a $500 \mathrm{~mL}$ Erlenmeyer flask as a koji and mash fermentation vessel and showed that the white-spored mutant could be used as a starter for preparation of kecap koji from the standpoint of preventing aflatoxin contamination ${ }^{5}$.

In order to apply the mutant K-1A to kecap production at a kecap factory in Indonesia, the first author was invited to JIRCAS during the period from July 4 through September 28 in 2001 under the counterpart researcher invitation program of JIRCAS and the second author stayed at the Research Center for Biology, Indonesian Institute of Sciences, for the period from January 28 through March 27 in 2002 as a JIRCAS short-term researcher. In these periods, we prepared an inoculum using the white-spored mutant, K-1A and applied it to kecap production at a kecap factory in Bogor, Indonesia.

\section{Materials and methods}

\section{Strains}

Aspergillus sp. K-1A was a white-spored mutant induced by irradiation of ultraviolet rays from the aflatoxin-negative koji mold, $\mathrm{K}-1^{5}$.

\section{Preparation of starter culture}

Thai rice obtained from a market in Japan was used in this study. After washing, the rice ( $20 \mathrm{~g}$ ) was soaked overnight at room temperature followed by draining for 1 h. The soaked rice was mixed with a slight tree ash $(0.2$ $\mathrm{g})^{4}$, put into a $300 \mathrm{~mL}$ Erlenmeyer flask and covered with a cotton plug, and autoclaved at $121^{\circ} \mathrm{C}$ for $15 \mathrm{~min}$. After cooling down, the autoclaved rice was inoculated with conidia (spore) suspension $(0.5 \mathrm{~mL})$ prepared with a slant culture on a potato dextrose agar (PDA, Difco, USA) of each strain and autoclaved $0.05 \%$ Tween 80 , incubated at $28^{\circ} \mathrm{C}$ for 4 days with shaking once after $24 \mathrm{~h}$ incubation and used as a spore inoculum. To determine germination ability after storing at $30^{\circ} \mathrm{C}$, the spore inoculum was placed in a desiccator which had saturated sodium chloride solution instead of a desiccant to keep at $75 \% \mathrm{RH}$ at $30^{\circ} \mathrm{C}$ for 3 weeks.

To prepare pure culture starter of K-1A for making kecap koji at a kecap factory, the Thai rice $(355 \mathrm{~g})$ was used. The soaked rice ( $71 \mathrm{~g}$ as raw material) was mixed with the tree ash $(0.7 \mathrm{~g})^{4}$, put into a Petri dish bottom (15 $\mathrm{cm}$ in diameter) and the lid which had a filter paper covered inside was replaced and autoclaved at $121^{\circ} \mathrm{C}$ for 15 min. After cooling down, the autoclaved rice was inoculated with about $0.5 \mathrm{~g}$ of the spore inoculum of K-1A and incubated at $30^{\circ} \mathrm{C}$ for 4 days with shaking once after $24 \mathrm{~h}$ incubation and dried at $42^{\circ} \mathrm{C}$ for 3 days, milled with a mixer (IFM model, Iwatani, Japan) and used as a starter culture.

\section{Kecap production}

(1) Traditional process

Kecap mash was prepared at the factory of Zebra Bogor Co. in Bogor, Indonesia, according to the traditional method employed by this company. Namely, black soybeans $(40 \mathrm{~kg})$ were soaked in water overnight, boiled for about $3 \mathrm{~h}$, spread on 10 bamboo trays (ca. $90 \mathrm{~cm}$ in diameter) and left for 9 days in the koji fermentation room (Fig. 1) of the factory at room temperature. The molded soybeans (kecap koji) were sun-dried for 2 days, winnowed to remove the hulls and spores, placed in a plastic pail and $70 \mathrm{~L}$ of hot water $\left(58^{\circ} \mathrm{C}\right)$ and $30 \mathrm{~kg}$ of salt were added to prepare kecap mash. Then the kecap mash was allowed to ferment for 2 months at room temperature with exposure to sunlight (Fig. 2).

(2) Kecap process with the starter culture of K-1A

Kecap koji was prepared using the starter culture. After spreading on 10 bamboo trays, cooked black soybeans (40 kg as raw material) were inoculated with $120 \mathrm{~g}$ of the starter culture of K-1A, and incubated for 3 days in the same koji fermentation room as the traditional process at room temperature. Then the kecap mash was prepared by the same process as the traditional process described above.

\section{Analytical methods}

(1) Moisture

Moisture was determined by the aluminum foil cup $\operatorname{method}^{9}$. A piece of aluminum foil $(15-20 \mathrm{~cm}$ square) was formed into a cup shape (ca. $5 \mathrm{~cm}$ in diameter, ca. 5 $\mathrm{cm}$ deep) using a bottom of a $100 \mathrm{~mL}$ beaker. Five grams of sample were weighed into an aluminum foil cup and heated at $105^{\circ} \mathrm{C}$ overnight in an oven and cooled in a desiccator for $30 \mathrm{~min}$.

(2) Nitrogen

After homogenizing kecap mash preparations with a small cup blender, total nitrogen (TN) was determined by Kjeldahl method. To determine water-soluble nitrogen (WN), $10 \mathrm{~g}$ of the homogenized kecap mash was diluted to $250 \mathrm{~mL}$ with distilled water. The resulting diluted suspension was centrifuged at $18,000 \mathrm{rpm}$ for $10 \mathrm{~min}$ and the supernatant was filtered. Nitrogen present in $20 \mathrm{~mL}$ of the filtrate was determined by Kjeldahl method. Formol nitrogen (FN) was determined according to the Kijun Miso Bunseki-Ho (Official Method of Miso Analysis) ${ }^{2}$. After neutralizing the supernatant $(50 \mathrm{~mL})$ with $0.1 \mathrm{~N}$ $\mathrm{NaOH}$ to $\mathrm{pH} 8.5$, formaldehyde $(20 \mathrm{~mL}, \mathrm{pH} 8.5)$ was added and the mixture was titrated with $0.1 \mathrm{~N} \mathrm{NaOH}$ to 


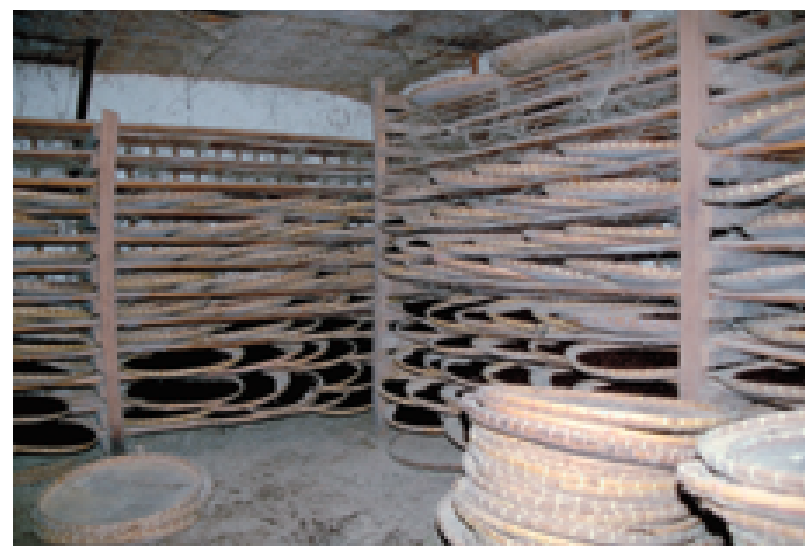

Fig. 1. Kecap koji fermentation room at Zebra Bogor Co. in Bogor, Indonesia

Boiled black soybeans were spread on bamboo trays (ca. $90 \mathrm{~cm}$ in diameter) and left for 9 days in this fermentation room at room temperature.

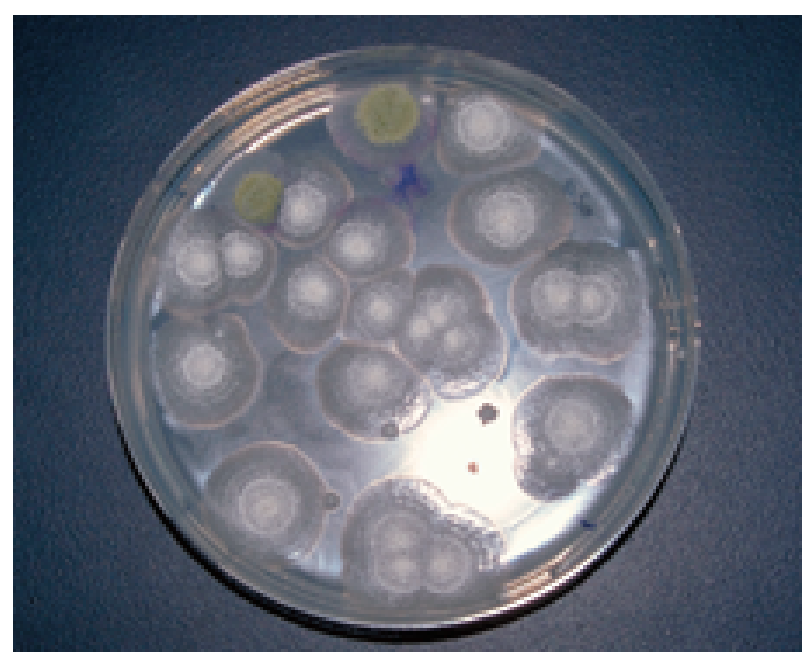

Fig. 3. Colonies of the white-spored mutant, K-1A (white colonies) and contaminated wild aspergilli (greenyellow colonies) on PDA

Kecap koji prepared using the starter culture was suspended in $0.05 \%$ Tween, spread on PDA and incubated for 3 days at room temperature.

pH 8.5.

(3) Sodium chloride

Sodium chloride was determined according to the method described in the Shokuhin Bunseki-Ho (Methods of Food Analysis $)^{8}$. The supernatant $(5 \mathrm{~mL})$ as prepared above was taken in a porcelain evaporating dish and titrated with $\mathrm{N} / 20$ silver nitrate in presence of $1 \mathrm{~mL} 2 \%$ potassium chromate as an indicator.

(4) Microbial analysis

Sample $(10 \mathrm{~g})$ was suspended in $90 \mathrm{~mL}$ of autoclaved $0.05 \%$ Tween 80 . For counting filamentous fungi, serial dilutions of the samples were prepared in the same solution and the diluted suspensions $(0.1 \mathrm{~mL})$ were spread on the plates of potato dextrose agar (PDA, Difco,

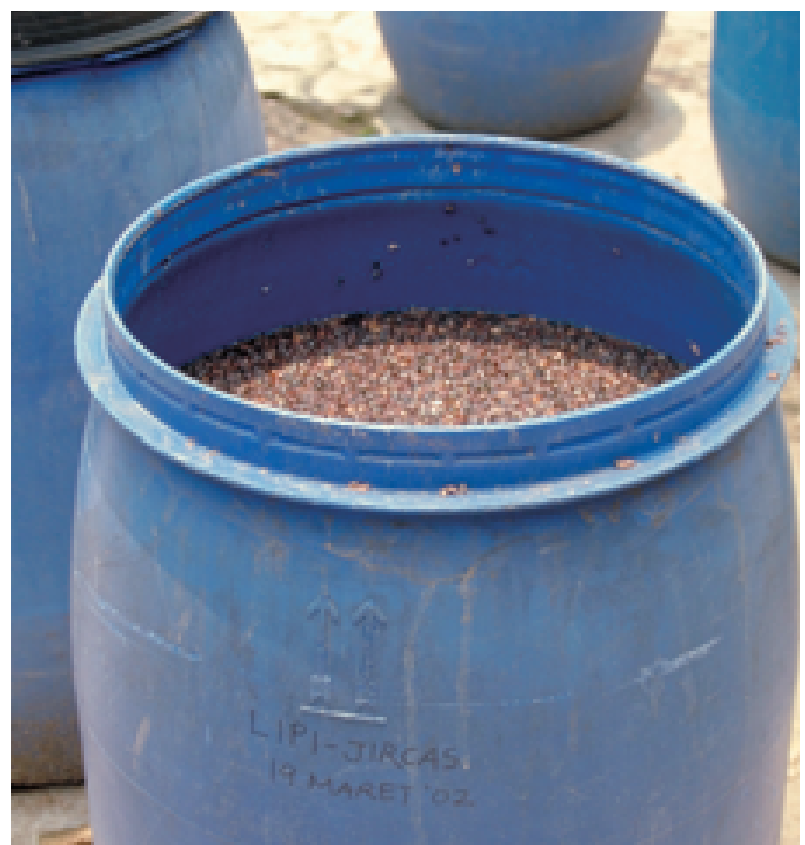

Fig. 2. Kecap mash fermentation at Zebra Bogor Co. in Bogor, Indonesia

Kecap mash was allowed to ferment for 2 months at room temperature with exposure to sunlight.

USA) containing $100 \mathrm{ppm}$ chloramphenicol. The plates were incubated for 1 to 3 days at room temperature. To count bacteria, $1 \mathrm{~mL}$ of diluted suspension was mixed with molten plate count agar consisting of $0.5 \%$ peptone (Difco, USA), $0.25 \%$ yeast extract (Difco, USA), $0.1 \%$ glucose and $1.5 \%$ agar and incubated for 1 to 3 days at room temperature.

(5) Count of spores of the mold strains

Number of spores was counted using a hemocytometer and a microscope ${ }^{1}$.

(6) Germination ability

Germination ability of the spores of the strains was assayed according to the method described in the Shoyu Shiken-Ho (Methods of Soy Sauce Studies) ${ }^{1}$ with minor modification. Namely, one drop of spore suspension in autoclaved $0.05 \%$ Tween 80 was placed on a thin layer of the koji extract agar prepared on an autoclaved object glass and then the object glass was placed on a $1.5 \%$ agar plate in a plastic Petri dish and incubated at $30^{\circ} \mathrm{C}$. After 6-8 h, germinated and ungerminated spores were counted using a microscope.

\section{Results and discussion}

\section{Preparation of starter culture}

Table 1 shows the spore counts and germination ability of the spore inoculum preparations. The number of spores developed on the cooked rice inoculated with 
Table 1. Spore counts and germination ability of the spore inoculum

\begin{tabular}{lcccc}
\hline \hline Strains & $\begin{array}{c}\text { Weight of } \\
\text { preparation* } \\
(\mathrm{g})\end{array}$ & $\begin{array}{c}\text { No. of } \\
\text { spores } \\
\end{array}$ & & \multicolumn{2}{c}{$\begin{array}{c}\text { Germination ability** } \\
(\%)\end{array}$} \\
\cline { 4 - 5 } K-1 & 26.3 & $1.7 \times 10^{9}$ & 92 & 89 \\
K-1A & 26.0 & $1.6 \times 10^{9}$ & 91 & 87 \\
\hline
\end{tabular}

*: Thai rice $(20 \mathrm{~g})$ and tree ash $(0.2 \mathrm{~g})$ were used for preparing each spore inoculum.

**: Germination ability was assayed after storing at $30^{\circ} \mathrm{C}$ and $75 \% \mathrm{RH}$
Table 2. Weights, moisture, germination ability and viable spore counts of the starter culture

\begin{tabular}{lcccc}
\hline \hline Strain & $\begin{array}{c}\text { Weight of } \\
\text { preparation* } \\
(\mathrm{g})\end{array}$ & $\begin{array}{c}\text { Moisture } \\
(\%)\end{array}$ & $\begin{array}{c}\text { Germination } \\
\text { ability } \\
(\%)\end{array}$ & $\begin{array}{c}\text { No. of } \\
\text { viable spores } \\
\text { (count/g) }\end{array}$ \\
\hline K-1 & 354 & 7.8 & 86 & $3.0 \times 10^{8}$ \\
K-1A & 363 & 7.7 & 86 & $3.0 \times 10^{8}$ \\
\hline
\end{tabular}

*: Thai rice $(355 \mathrm{~g})$ and tree ash $(3.5 \mathrm{~g})$ were used for preparing each starter culture.

Table 3. Moisture and microbial counts in kecap koji

\begin{tabular}{|c|c|c|c|c|c|}
\hline & \multirow{3}{*}{$\begin{array}{l}\text { Moisture } \\
(\%)\end{array}$} & \multicolumn{3}{|c|}{ Mold* (cfu/g) } & \multirow{3}{*}{$\begin{array}{l}\text { Viable bacteria** } \\
(\mathrm{cfu} / \mathrm{g})\end{array}$} \\
\hline & & \multicolumn{2}{|c|}{ Aspergillus } & \multirow[t]{2}{*}{ Rhizopus/Mucor } & \\
\hline & & $\mathrm{K}-1 \mathrm{~A}$ & Others & & \\
\hline Cooked soybeans & 68.5 & & & & \\
\hline \multicolumn{6}{|c|}{ Traditional Koji (9 days incubation) } \\
\hline Koji after fermentation & 36.5 & - & $2.3 \times 10^{7}$ & $5.0 \times 10^{6}$ & $4.1 \times 10^{9}$ \\
\hline Sun-dried koji & 7.3 & - & $2.8 \times 10^{6}$ & $1.5 \times 10^{5}$ & $2.6 \times 10^{9}$ \\
\hline \multicolumn{6}{|c|}{ K-1A Koji (3 days incubation) } \\
\hline Koji after fermentation & 54.9 & $2.3 \times 10^{7}$ & $2.0 \times 10^{6}$ & $1.4 \times 10^{5}$ & $8.6 \times 10^{8}$ \\
\hline Sun-dried koji & 8.1 & $8.6 \times 10^{6}$ & $1.0 \times 10^{6}$ & $1.3 \times 10^{5}$ & $1.8 \times 10^{9}$ \\
\hline
\end{tabular}

*: Number of colonies on PDA containing $100 \mathrm{ppm}$ chloramphenicol after 3-day incubation at room temperature.

**: Number of colonies on plate count agar after 3-day incubation at room temperature.

$\mathrm{K}-1 \mathrm{~A}$ was not so different from that of K-1. Both germination ability of K-1A before storing and after storing also were not so different from those of $\mathrm{K}-1$, respectively. These results show that there were not so many differences in spore productions and in germination ability of spores between the original strain and its white-spored mutant. However, the spore inoculum prepared with the mutant K-1A had white color spores which could be distinguished from that prepared with the original koji strain.

Next, a starter culture for the study on kecap koji fermentation carried out at Zebra Bogor Co. in Indonesia was prepared. Table 2 shows germination ability and viable spore counts of the starter preparations. There were not so many differences in the germination ability and in the number of viable spores between the two preparations. The preparation using the K-1A strain was used for kecap production at Zebra Bogor Co.

\section{Kecap production at a kecap factory}

(1) Preparation of kecap koji

Kecap kojis were prepared by the conventional method (without inoculum) and the newly developed method using the starter culture. While the kecap koji making process took 9 days by the conventional method (without inoculum), the use of the K-1A strain as the starter shortened the process to 3 days at room temperature.

Moisture contents and microbial counts in koji preparations are shown in Table 3. Both koji preparations contained approximately $10^{8} \mathrm{cfu} / \mathrm{g}$ of bacteria. The traditionally prepared kecap koji contained $2.3 \times 10^{7} \mathrm{cfu} / \mathrm{g}$ of aspergilli and $5.0 \times 10^{6} \mathrm{cfu} / \mathrm{g}$ of Mucorales. Since the inoculated strain K-1A developed white spores during incubation, the mutant could be distinguished from the contaminated aspergilli by their appearances on the agar plates (Fig. 3). The koji prepared using the inoculum contained $2.3 \times 10^{7} \mathrm{cfu} / \mathrm{g}$ of K-1A as the dominant mold, even though it contained contaminants, $2.0 \times 10^{6} \mathrm{cfu} / \mathrm{g}$ of aspergilli and $5.0 \times 10^{6} \mathrm{cfu} / \mathrm{g}$ of Mucorales from the environment. This result shows that the number $(\mathrm{cfu} / \mathrm{g})$ of contaminated Aspergillus in the kecap koji from the environment decreased to $1 / 10$ by using the starter culture of K-1A.

After sun-drying, the moisture contents decreased to 7 to $8 \%$. 
Table 4. Formol nitrogen (FN), water-soluble nitrogen (WN), total nitrogen (TN) and $\mathrm{NaCl}$ contents, and $\mathrm{pH}$ values of kecap mash

\begin{tabular}{|c|c|c|c|c|c|c|c|c|}
\hline & \multirow{2}{*}{$\begin{array}{l}\text { Fermentation } \\
\text { period* } \\
\text { (day) }\end{array}$} & \multirow[t]{2}{*}{$\mathrm{pH}$} & \multirow[t]{2}{*}{$\mathrm{NaCl}(\%)$} & \multicolumn{3}{|c|}{ Nitrogen } & \multirow[t]{2}{*}{ FN/TN (\%) } & \multirow[t]{2}{*}{ WN/TN (\%) } \\
\hline & & & & FN (\%) & WN (\%) & TN (\%) & & \\
\hline \multirow[t]{2}{*}{ Control } & 42 & 5.5 & 20.8 & 0.17 & 0.68 & 1.65 & 10.3 & 41.2 \\
\hline & 60 & 5.5 & 21.0 & 0.26 & 0.83 & 1.98 & 13.1 & 41.9 \\
\hline \multirow[t]{4}{*}{$\mathrm{K}-1 \mathrm{~A}$} & 2 & 5.7 & 21.0 & 0.15 & 0.40 & 1.12 & 13.4 & 35.7 \\
\hline & 14 & 5.6 & 20.9 & 0.24 & 0.65 & 1.35 & 17.8 & 48.2 \\
\hline & 42 & 5.5 & 20.3 & 0.35 & 0.77 & 1.57 & 22.3 & 49.0 \\
\hline & 60 & 5.5 & 20.6 & 0.42 & 0.91 & 1.61 & 26.1 & 56.5 \\
\hline
\end{tabular}

*: Kecap mash fermentation was carried out at room temperature.

Control: Kecap mash was prepared by the conventional and traditional method (without inoculum).

K-1A: Kecap mash was prepared using the kecap koji inoculated with the starter culture of K-1A.

\section{(2) Kecap mash fermentation}

Kecap mashes were prepared with each kecap koji and allowed to ferment. Table 4 shows total nitrogen contents, water-soluble nitrogen, formol nitrogen, sodium chloride, and $\mathrm{pH}$ values during fermentation. The $\mathrm{pH}$ value of both the mashes indicated 5.5 after 2 months of fermentation and they contained about $21 \%$ salt. The contents of formol nitrogen and water-soluble nitrogen increased with the fermentation time. After 2 months of fermentation, the kecap mash prepared with kecap koji inoculated with the K-1A strain showed higher contents of formol nitrogen and water-soluble nitrogen than that prepared without the starter. These results demonstrate that the use of the white-spored mutant as the starter not only contributes to the prevention of aflatoxin contamination but also improves the conventional kecap fermentation process.

The water-soluble nitrogen of the total nitrogen reached $56.5 \%$ after 2 months of fermentation when the starter culture was used. However, this value was lower than that of the result described in our previous paper ${ }^{5}$ using a $500 \mathrm{~mL}$ Erlenmeyer flask as a fermentation vessel at the laboratory. The temperature of the hot water used for the kecap mash preparation was $58^{\circ} \mathrm{C}$ in this study, while water at room temperature was used in our previous work ${ }^{5}$. The hot water might have inactivated proteases of the kecap koji when the kecap mash was prepared at Zebra Bogor Co. There was much room for improvement in the kecap production process.

\section{Acknowledgments}

We would like to express our sincere gratitude to associated scientists and staff of the Research Center for Biology, Indonesian Institute of Sciences and JIRCAS for their advice and contributions. We wish to thank Ms.
Yati S. Soeka, Ms. Elidar Naiola, and Ms. Devira Ferina for their assistance in carrying out experiments.

This research was funded by the JIRCAS research project entitled "Development of new processing technology for quality improvement of indigenous soybean foods in developing regions".

\section{References}

1. Editorial Committee for Society for Shoyu Shiken-ho and Japan Soy Sauce Research Institute (ed.) (1985) Tanekoji (Mold spore inoculum). In Shoyu shiken-ho (Methods of soy sauce stud.), Nihon Shoyu Kenkyujo, Tokyo, Japan, 275-279 [In Japanese].

2. Institute of Miso Technologists (1968) Kijun miso bunseki-ho (Official method of miso analysis), Institute of Miso Technologists, Tokyo, Japan, 28-29 [In Japanese].

3. Judoamidjojo, M. (1986) The studies on Kecap-indigenous seasoning of Indonesia. Mem. Tokyo Univ. of Agric., 28, 100-159.

4. Narahara, H. (1987) Moyashi (Mold spore inoculum). In Koji gaku (Koji sci. \& technol.), Brewing Society of Japan, Tokyo, Japan, 32-47 [In Japanese].

5. Nikkuni, S. et al. (2002) Application of white-spored mutants induced from koji molds for the production of Indonesian soy sauce (kecap). Mycotoxins, 52 (1),13-22.

6. Sadjono, Kapti, R. \& Sudarmadji, S. (1992) ASEAN Food $J ., 7,30-33$.

7. Steinkraus, K. H. (ed.) (1995) Indonesian soy sauce: kecap. In Handbook of indigenous fermented foods, 2nd ed. Marcel Dekker, New York, USA, 539-543.

8. Tsutsumi, C. (1982) Shokuen oyobi enso ( $\mathrm{NaCl}$ and $\mathrm{Cl})$. In Shokuhin bunseki-ho (Methods of food anal.), ed. Japanese Society for Food Science and Food Technology and Editorial Committee for Shokuhin Bunseki-Ho, Korin, Tokyo, Japan, 363-385 [In Japanese].

9. Tsutsumi, C. (1996) Suibun (Moisture). In Shin shokuhin bunseki-ho (Methods of food anal., new ed.), ed. Japanese Society for Food Science and Food Technology and Editorial Committee for Shin Shokuhin Bunseki-ho, Korin, Tokyo, Japan, 5-29 [In Japanese]. 